\title{
Chuseok and Henry James in Korea
}

DOI: http://dx.doi.org/10.12775/LC.2017.025

Date: Mon, 5 Oct 2015 15:13:34+0900

From: Conference HJS <henryjamesvoyage21@gmail.com>

Re: 2017 Henry James International Conference

To: Miroslawa.Buchholtz@umk.pl

Dear Professor Miroslawa Buchholtz,

Thank you for your email and please accept my apologies for my delay in responding. I've been away from my email these past 2 weeks for Chuseok Korean Thanksgiving Day. Regarding Chuseok in Korean Culture: on the morning of the day of Chuseok, August 15th according to the lunar calendar (usually September in solar calendar) when the full harvest moon appears, family members gather at homes [of the eldest son of the eldest son's family] to hold memorial services in honor of our ancestors.

And we all visit our ancestral graves during Chuseok [before and/or after the day]. During this visit, family members [usually men] remove the weeds that have grown around the graves in the summer season - a duty and expression of devotion and respect for our family.

The Henry James Society of Korea was established in 1996 with the Journal of the Henry James Studies. It was first published in 1996 and discontinued in 2004. [Please find attached the pictures for your reference: front and back cover images of the first number of the journal]. We try to revive the publication of the journal in the near future, perhaps next year... I'll let you know when our website is ready for launch. Any thoughts/suggestions on our 2017 conference are welcome! I'd appreciate to have your publications to read and share ideas with you through them. Many thanks, Professor Miroslawa Buchholtz, for your concern and kind attention to the activities of Henry James Society of Korea.

Sincerely,

Choon-Hee Kim

Choon-Hee Kim, Ph. D.

Theatre Critic

President of the Henry James Society, Korea Researcher, Institute of Humanities, Seoul National University Visiting Professor, International Affairs Division, Sungkyunkwan University Address:

Henry James Society, Boramae Hyundai \#1706, Shindaebang-dong 395-65,

Dongjak-gu, Seoul 156-729, Republic of Korea (South Korea)

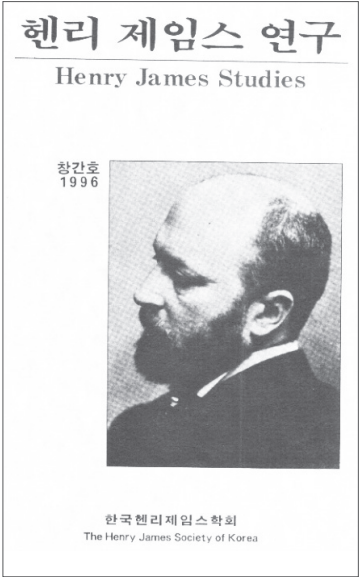

\section{7}

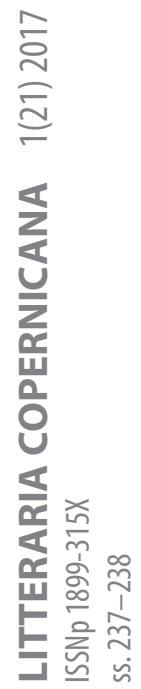


Quiz: hinged doors opening straight upon life / drzwi, które otwierają się prosto na życie

The house of fiction has in short not one window, but a million (...). These apertures, of dissimilar shape and size, hang so, all together, over the human scene that we might have expected of them a greater sameness of report than we find. They are but windows at the best, mere holes in a dead wall, disconnected, perched aloft; they are not hinged doors opening straight upon life. (Preface to The Portrait of a Lady)

Dom fikcji literackiej ma, krótko mówiąc, nie jedno, lecz milion okien (...). Wszystkie te otwory, o różnych kształtach i rozmiarach, wiszą nad sceną ludzkiego życia i moglibyśmy oczekiwać, że opisy tego, co z nich widać, będą do siebie bardziej podobne niż w rzeczywistości. Otwory te są w najlepszym wypadku tylko oknami, dziurami w martwej ścianie, oddzielonymi od siebie nawzajem, gdzieś wysoko nad ziemią; nie są to drzwi, które otwierają się prosto na życie. (Przedmowa do Portretu damy, thum. Marcin Szuster, „Literatura na Świecie” 05-06/2016, s. 309-326)
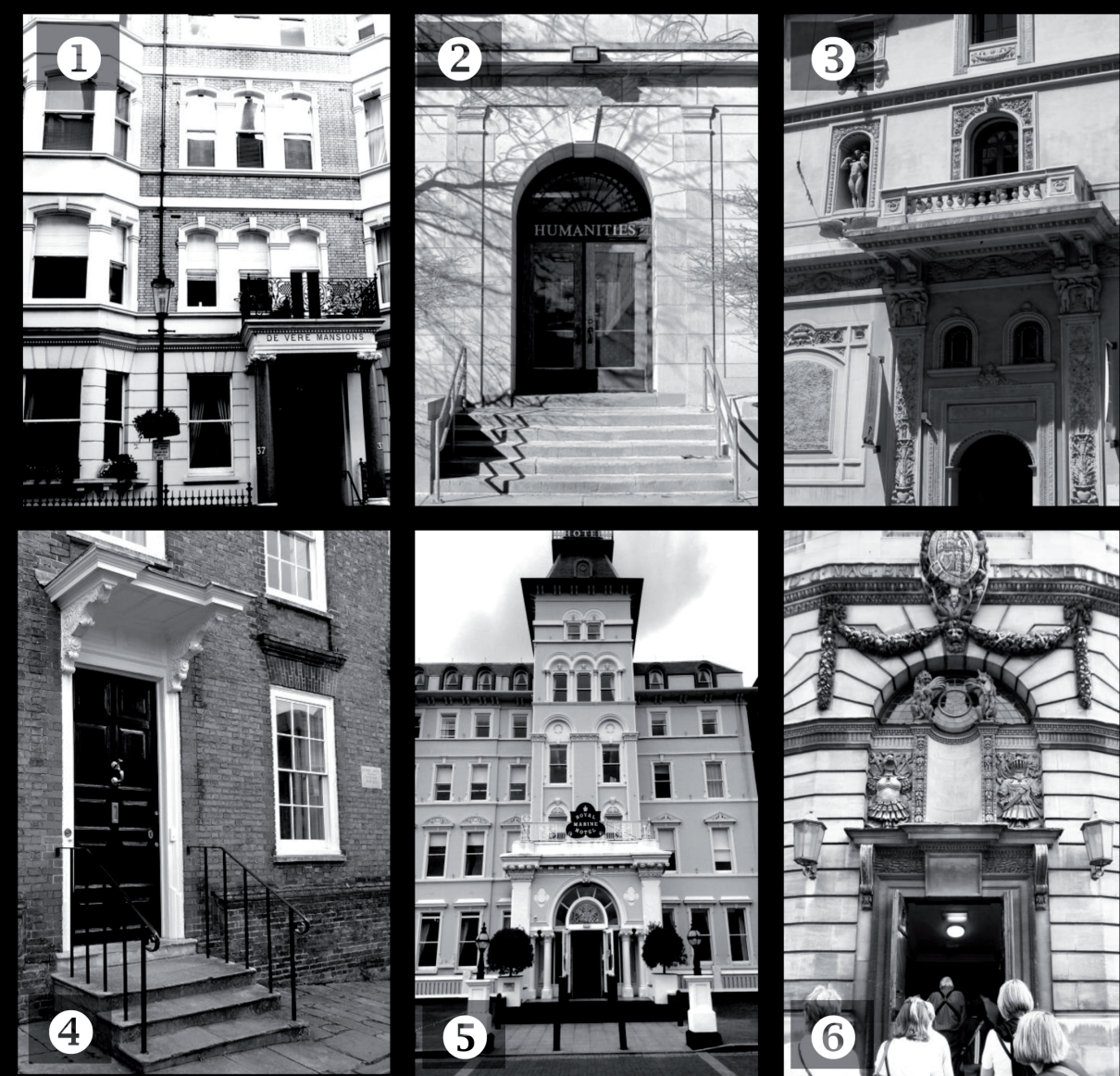

Do you recognize these doors?

Write to us about your "door" to Henry James: Miroslawa.Buchholtz@umk.pl, gutt@umk.pl, gregorex@umk.pl

Czy rozpoznają Państwo te drzwi? Jak wyglądają Państwa „drzwi”,

do Henry’ego Jamesa? Czekamy na e-maile: Miroslawa.Buchholtz@umk.pl,

gutt@umk.pl, gregorex@umk.pl
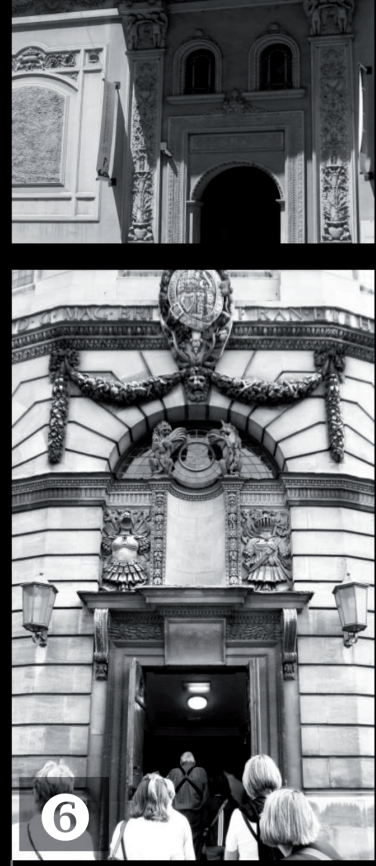

Photographs by: / Autorzy zdjeć: 2) Greg Zacharias 4) Sonoko Saito 5) Grzegorz Koneczniak 